\title{
Economic growth and its key factors: an alternative view on the factors stimulating agriculture growth
}

\author{
Prateep Wajeetongratana ${ }^{1, *}$ \\ ${ }^{1}$ FMS, Suan Sunandha Rajabhat University, 1 U-Thong Nok rd, 10200, Dusit, Bangkok, Thailand
}

\begin{abstract}
This research study makes an attempt to study the impacts of natural resources as well as financial and labor factors on economic development of contemporary states. Also, it investigates the correlation between all these factors mentioned above, in the context of countries' economic growth. The obtained here results have helped us determine the core reasons behind international migration as a global phenomenon applicable to all countries without exceptions. Indirectly, we also demonstrate the transforming role of the labour factor as applied to economic development of countries and regions. Finally, positive impacts of a set of manufacturing factors on both international and domestic markets are demonstrated.
\end{abstract}

\section{Introduction}

Factors and impacts behind countries' economic growth as well as behind global economic progress overall have always been among the top priorities of academic research $[1 ; 2 ; 3 ; 4 ; 5]$. Analysis of economic growth, its cycles, stages, alternative scenarios along with the analysis of all the resources needed for such growth form the basis for socioeconomic forecasting, national economic strategizing attempts and all development policies.

Economic growth is the key criteria for any nationwide system, social welfare system in the first place. Growth is also the key result for any government nationwide effort and the central indicator of national wellbeing. To some extent, economic growth can even be seen as a guarantee of country's autonomy. Stable economic growth is the key proof that a country's economic system is "healthy" and thus - its society is safely protected from potential economic risks and external economic threats.

Therefore, economic growth would be always a top priority in development of a national macroeconomic policy, in any state. At the same time, all countries are inevitably connected through the systems of complex economic, political, social, cultural etc. relations. In all these relations, the key roles belong to regulators (international and national) and also to the largest businesses (so-called transnational corporations) $[6 ; 7 ; 8$; 9]. Under such complex conditions of growing economic/business globalization, economic

\footnotetext{
*Corresponding author: prateep.wa@ssru.ac.th
} 
growth of countries is doomed to be asynchronous, as it is always predetermined by international economic layout and by internal potential of a country itself [10]. In other words, local criteria of economic development will always be drastically different.

Traditionally $[11 ; 12 ; 13 ; 14]$, academic and expert literature identifies several key factors which together predetermine country's economic growth. These factors are: availability and richness of local natural resources; financial capacity; labour potential and its size; the level of country's tech development (today this would assume country's digitization first of all).

In this study below we are making an attempt to define the role of each of these factors (mainly, resources, finance and labor) in the ongoing economic development of the selected countries.

We would like to start with noting that this study's concentration on these three groups of factors (above) does not mean that we totally disregard the meaningful impact of innovative and technological factors when in comes to economic development [15]. In fact, here we consider all potential innovative factors as part of a much larger factor - labour potential. This approach to understanding the innovative factors of economic growth we explain in the following way: there is an obvious and very much direct correlation between the level of skills present among labour force and the innovative potential of a country overall. In other words, quality of human resources in a country largely predetermines the innovative capacity of its public and private organizations. Further, certain level of skills and knowledge in the society is needed for both generation and consumption of various innovations, no matter what is the field of their immediate application $[16 ; 17 ; 18 ; 19]$.

The central objective of our study here is to define (stemming from the analysis of key macroeconomic indicators across countries) the importance of three vital parameters availability of natural resources, quality of labour resources and access to finance - as all three are stabilizing the dynamics of economic development across the globe.

Following this central objective, the following study tasks have been supplemented for specification purposes:

- to analyse in detail the impact of countries' resource potential on their economic growth through calculation of resource use efficiency;

- to determine the role of free access to finance in a country for the improvement of its macroeconomic indicators and economic growth rate;

- to prove the meaningful role of human resource potential for the world economic progress overall and by countries;

- to outline the dynamics of economic growth factors in their dynamics for several years in a row;

- to prove and explain the presence of correlation between the use efficiency of natural, labour and financial resources on the one hand the the rates of economic growth on the other.

From these study tasks above, we have also formulated the following research hypotheses:

H1: Economic growth in most countries tends to cause disproportions in the costs of human resources, natural resources and financial resources.

$\mathrm{H} 2$ : In the course of economic growth, the factor of access to finance tends to demonstrate lowering efficiency.

H3: In case of developed countries, human resource factor is the most important one in relation to economic growth.

$\mathrm{H} 4$ : In case of developing countries, financial resources and access to them are the most important factors for economic growth.

H5: The larger is the resource potential of a country - the less important the natural resource potential factor is for economic growth of this country. 


\section{Research methodology}

Our key source of data for this study has been the statistical database of the World Bank, available openly at www.worldbank.org.

To measure the factor of natural resources in the selected countries we have synthesized an indicator which is aggregating the following parameters: the preliminary estimated value of land areas and natural resources in a country; the relative share of mining in country's GDP; relative competitiveness of a country's mining sector; energy capacity of country's economic system; the degree of energy concentration in a country; energy efficiency of country's economy; country's share in the global trade in natural resources.

To measure the financial resource factor we have also calculated a synthesized indicator consisting of the following parameters: degree of economy's capitalization; yearly balance of payments; capitalization of country's stock exchange; liquidity of a national economic system; the volume of investments in fixed assets.

To measure the labour factor we have been using the following, rather classical, macroeconomic indicators: capacity of a local labour market; labour productivity; GDP per employed person; the rate of unemployment in a country; overall structure of employment in a country.

The time scope of our study is 2010 to 2018 since part of the needed data is not yet available for 2019. All indicators have been analyzed in their dynamics through these years.

\section{Research Results}

First and foremost, our research results (see Tables below) prove that there is an obvious stimulating impact of natural, labour and financial resources on economic growth. At least, in the countries we have selected for our analysis.

From Table 1, it is rather obvious that the role of natural resources is especially obvious for actively developing countries in such regions as South-East Asia and Latin America. At this, in case of already quite developed countries (EU and USA in the first place) the factor of natural resources can hardly be called stimulating at all. Same can be stated for small countries, such as Georgia, Iceland and Lithuania.

For additional verification of our hypothesis concerning natural resources we then carried out a comparative analysis by groups of countries. Our first set of countries consists of largest and smallest countries (among those selected for the purposes of out analysis). We have decided to take the size factor into account since land is one of the most vital natural resources in any country. Comparison by these two groups is presented in Table 2 .

The results of our comparative analysis demonstrate that the role of natural resource factor in economic development of countries does not depend on the dynamics of natural resource potential growth. At the same time, we cannot state that there is homogeneity inside the groups. If we look closer at top-5 and bottom-5 in both groups, the results are manifold different!

Another interesting approach would be testing the impact of the natural resource factor on economic growth for the countries most interested in these natural resources - that is, on the well-known exporters of oil, gas and metals. Our results on this correlation are presented in Table 3. 
Table 1. Stimulating impact of natural resources factor on economic growth of the selected countries, as of 2018 (Authors' own calculations).

\begin{tabular}{|c|l|c|c|l|c|}
\hline & Top-15 & $\begin{array}{l}\text { Stimulating impact index } \\
\text { (The maximum value (100) } \\
\text { means a country is } \\
\text { developing solely thanks to } \\
\text { natural resources) }\end{array}$ & & Lower 15 & $\begin{array}{c}\text { Stimulating } \\
\text { impact } \\
\text { index }\end{array}$ \\
\hline 1 & Indonesia & 82.83 & 58 & Norway & 24.84 \\
\hline 2 & Colombia & 77.28 & 59 & Czech Republic & 24.66 \\
\hline 3 & Peru & 76.5 & 60 & Holland & 24.61 \\
\hline 4 & Bangladesh & 75.83 & 61 & USA & 24.29 \\
\hline 5 & Algeria & 73.22 & 62 & Brazil & 23.71 \\
\hline 6 & Panama & 73.09 & 63 & Lithuania & 22.8 \\
\hline 7 & Thailand & 72.51 & 64 & Russia & 22.53 \\
\hline 8 & Sri Lanka & 67.95 & 65 & Sweden & 21.34 \\
\hline 9 & Ecuador & 67.14 & 66 & Canada & 21.13 \\
\hline 10 & Croatia & 63.86 & 67 & UAE & 20.92 \\
\hline 11 & Philippines & 62.4 & 68 & Australia & 19.86 \\
\hline 12 & Morocco & 61.05 & 69 & Finland & 18.32 \\
\hline 13 & Argentina & 58.71 & 70 & Uzbekistan & 12.27 \\
\hline 14 & South Korea & 58.35 & 71 & Georgia & 9.78 \\
\hline 15 & India & 58.21 & 72 & Iceland & 9.48 \\
\hline & & & & Average & 23.1 \\
\hline
\end{tabular}

Table 2. Comparison of stimulating impact for the largest and smallest countries in the world, as of 2018 (Authors' own calculations).

\begin{tabular}{|c|c|c|c|c|}
\hline $\begin{array}{c}\text { Stimulating } \\
\text { impact index }\end{array}$ & $\begin{array}{c}\text { TOP-15 smallest } \\
\text { countries }\end{array}$ & $\begin{array}{c}\text { TOP-15 largest } \\
\text { countries }\end{array}$ & $\begin{array}{c}\text { Stimulating } \\
\text { impact index }\end{array}$ \\
\hline 67.15 & Belize & 1 & Argentina & 77.20 \\
\hline 30.45 & Cape Verde & 2 & Peru & 76.77 \\
\hline 33.52 & Singapore & 3 & Indonezia & 75.80 \\
\hline 33.24 & Holland & 4 & India & 63 \\
\hline 72.55 & Seychelles & 5 & Bolivia & 58.77 \\
\hline 31.75 & Denmarks & 6 & Algeria & 57.60 \\
\hline 24.68 & Lithuania & 7 & South Africa & 53.33 \\
\hline 63.86 & Slovenia & 8 & Brazil & 52.71 \\
\hline 24.61 & Iceland & 9 & China & 43.17 \\
\hline 73 & Uruguay & 10 & USA & 31.18 \\
\hline 62 & Senegal & 11 & Russia & 25.29 \\
\hline 25.31 & Latvia & 12 & Canada & 22.55 \\
\hline 36.65 & Mauritius & 13 & Kazakhstan & 21.13 \\
\hline 35.63 & Puerto Rico & 14 & Australia & 20.92 \\
\hline 30.92 & Armenia & 15 & Saudi Arabia & 19.88 \\
\hline 42.91 & & & 46.5 \\
\hline
\end{tabular}

Table 3. The index of stimulating impact of the natural resource factor in case of well-known exporters of natural resources (Authors' own calculations).

\begin{tabular}{|c|l|c|c|l|c|}
\hline Countries & $\begin{array}{c}\text { The index of } \\
\text { natural resource } \\
\text { impact }\end{array}$ & & Countries & $\begin{array}{c}\text { The index of } \\
\text { natural resource } \\
\text { impact }\end{array}$ \\
\hline 1 & Norway & 18.36 & 8 & Russia & 30.25 \\
\hline 2 & Saudi Arabia & 20.88 & 9 & South Africa & 44.45 \\
\hline 3 & Canada & 21.15 & 10 & Malaysia & 56.49 \\
\hline 4 & Kazakhstan & 22.45 & 11 & Chile & 55.55 \\
\hline
\end{tabular}




\begin{tabular}{|c|l|c|c|l|c|}
\hline 5 & Venezuela & 23.07 & 12 & Mexico & 57.06 \\
\hline 6 & United States & 24.33 & 13 & Brazil & 58.55 \\
\hline 7 & UAE & 25 & 14 & Indonesia & 60.04 \\
\hline & & & & Median index & 37.7 \\
\hline
\end{tabular}

Table 4. Comparison of 15 richest and 15 poorest countries in terms of resource factor impact on economic development, as of 2018 (Authors' own calculations).

\begin{tabular}{|c|c|c|c|c|}
\hline $\begin{array}{c}\text { Index of } \\
\text { impact }\end{array}$ & $\begin{array}{c}\mathbf{1 5} \\
\text { richest countries }\end{array}$ & $\begin{array}{c}\mathbf{1 5} \\
\text { poorest economies }\end{array}$ & $\begin{array}{c}\text { Index of } \\
\text { impact }\end{array}$ \\
\hline 9.49 & Iceland & 1 & Kyrgyzstan & 12.22 \\
\hline 9.44 & Norway & 2 & Liberia & 25.57 \\
\hline 9.77 & Canada & 3 & Niger & 30.44 \\
\hline 12 & Australia & 4 & Malawi & 35.2 \\
\hline 18.34 & Finland & 5 & Zambia & 52 \\
\hline 19.80 & USA & 6 & Pakistan & 52.6 \\
\hline 20.99 & Germany & 7 & Nepal & 52.77 \\
\hline 21.16 & Sweden & 8 & Egypt & 53.81 \\
\hline 21.48 & UK & 9 & Kenya & 58.24 \\
\hline 22.57 & Netherlands & 10 & Cambodia & 58.33 \\
\hline 22.44 & Switzerland & 11 & India & 62.48 \\
\hline 23.73 & Denmark & 12 & Honduras & 72.59 \\
\hline 24.11 & Japan & 13 & Indonesia & 75 \\
\hline 24.63 & Qatar & 14 & Moldova & 77.33 \\
\hline 24.89 & Belgium & 15 & Myanmar & 82.44 \\
\hline
\end{tabular}

Table 5. The index of natural resource factor in BRICS economies, as of 2018 (Authors' own calculations).

\begin{tabular}{|c|c|c|}
\hline & Country & The index \\
\hline 1 & India & 75.9 \\
\hline 2 & Brazil & 58.2 \\
\hline 3 & China & 53.1 \\
\hline 4 & South Africa & 43.11 \\
\hline 5 & Russia & 30.22 \\
\hline & Median in group & 52.106 \\
\hline
\end{tabular}

Our final testing attempt regarding natural resource potential covers the correlation between the impact of natural resources and countries' GDP per capita. Data on this correlation clearly confirms that in developed countries the influence of natural resources' availability and potential is much lower than in developing ones (Table 4).

Calculations in Table 4 demonstrate that in the countries with very low GDP per capita the impact of natural resource factor remains vital for their economic development. This can be partially explained by the fact that such underdeveloped countries usually lack other resources, financial ones and also knowledge in the first place. Thus, they are forced to compensate for the lack of other resources through extremely intensive (if not aggressive) use of their natural potential. At the same time, this indirectly proves that these countries urgently need to come up with brand new and much more efficient scenarios for their economic growth.

Table 6. Financial impact on economic growth in the selected countries (top-15 and lowest-15), as of 2018 (Authors' own calculations).

\begin{tabular}{|c|l|c|c|l|c|}
\hline № & \multicolumn{1}{|c|}{ Top-15 } & $\begin{array}{c}\text { Financial impact } \\
\text { factor }\end{array}$ & № & Lowest-15 & $\begin{array}{c}\text { Financial } \\
\text { impact factor }\end{array}$ \\
\hline 1 & Ecuador & 91.03 & 58 & Germany & 4.89 \\
\hline 2 & Georgia & 86.5 & 59 & Singapore & 4.71 \\
\hline
\end{tabular}




\begin{tabular}{|c|l|c|c|l|c|}
\hline 3 & Uzbekistan & 86.88 & 60 & Malaysia & 4.35 \\
\hline 4 & Kenya & 66.75 & 61 & France & 4.22 \\
\hline 5 & Zambia & 65.1 & 62 & Spain & 4.17 \\
\hline 6 & Armenia & 62.26 & 63 & Argentina & 4.15 \\
\hline 7 & Lithuania & 59.06 & 64 & Belgium & 3.33 \\
\hline 8 & Albania & 59.04 & 65 & Sweden & 3.2 \\
\hline 9 & Moldova & 57.94 & 66 & Norway & 3 \\
\hline 10 & Ghana & 57.42 & 67 & Canada & 2.77 \\
\hline 11 & Venezuela & 52.99 & 68 & Australia & 2.72 \\
\hline 12 & Honduras & 51.66 & 69 & Finland & 2.5 \\
\hline 13 & Poland & 50 & 70 & UK & 2.37 \\
\hline 14 & Azerbaijan & 45.93 & 71 & USA & 2.24 \\
\hline 15 & Ukraine & 45.82 & 72 & Italy & 1.89 \\
\hline
\end{tabular}

On the other hand, in some developed countries (including USA or Norway) the factor of natural resource potential is important but still clearly not the core one. Roughly speaking, economic success of the richest countries in the world is only about $20-25 \%$ dependable on their internal natural resources. To compare, in case of the poorest countries we can state that this share is larger than $50 \%$.

Here we would like to make a slight digression in order to consider the same impact of the natural resource factor, but strictly within one group of countries - namely, BRICS. This group is commonly considered to be one of the most promising and curious ones in terms of economic development rates and trends. Let's have a closer look on the interesting differences inside this group (see Table 5).

Data provided in Table clearly shows that the role of natural resources within the BRICS group is quite different. Russian result is especially curious: despite the fact that natural resources (oil and gas in the first place) contribute truly huge amounts to the federal budget, the role of these resources for Russia's growth is not significant, twice less than in India, in fact. Thus, we have all the reasons to state that (relatively) fast rate of economic development in this group is support not by their resource base.

Now, let us move to our second indicator - the impact of access to financial resources. We are of the opinion that the most appropriate measure for such an analysis would be "saturation with capital". Our calculations on the selected countries are presented in Table 6.

Table 7. The impact of labour factor on economic development rates of the selected countries, top- 15 and bottom-15, as of 2018 (Authors' own calculations).

\begin{tabular}{|c|l|c|c|l|c|}
\hline $\begin{array}{c}\text { Ran } \\
\mathbf{k}\end{array}$ & \multicolumn{1}{|c|}{ Top-15 } & $\begin{array}{c}\text { The labour } \\
\text { factor index }\end{array}$ & Rank & \multicolumn{1}{|c|}{ Bottom-15 } & $\begin{array}{c}\text { The labour } \\
\text { factor index }\end{array}$ \\
\hline 1 & Sweden & 78.47 & 58 & Indonesia & 9.98 \\
\hline 2 & New Zealand & 77.21 & 59 & Brazil & 9.81 \\
\hline 3 & Norway & 76.55 & 60 & India & 9.44 \\
\hline 4 & USA & 73.82 & 61 & Kenya & 9 \\
\hline 5 & Finland & 73.45 & 62 & Zambia & 8.88 \\
\hline 6 & Ireland & 72.68 & 63 & Bolivia & 7.38 \\
\hline 7 & Qatar & 72.38 & 64 & Kazakhstan & 7.21 \\
\hline 8 & Singapore & 72 & 65 & Ukraine & 7.17 \\
\hline 9 & Germany & 71.05 & 66 & Thailand & 5.75 \\
\hline 10 & Belgium & 65.65 & 67 & Uruguay & 5.44 \\
\hline 11 & Denmark & 64.66 & 68 & Tanzania & 5.42 \\
\hline 12 & Hong Kong & 64.72 & 69 & Moldova & 2.36 \\
\hline 13 & Netherlands & 63.64 & 70 & Panama & 2.02 \\
\hline 14 & South Korea & 62.09 & 71 & Sri Lanka & 2.01 \\
\hline 15 & Australia & 58.15 & 72 & Uzbekistan & 1.53 \\
\hline
\end{tabular}


Calculations presented in Table 6 allow us put forward the following assumptions:

- the financial factor is vitally important for those developing countries that has large natural reserves (look at Venezuela or Azerbaijan, for example). At the same time, it is no less important for small countries with hardly any natural reserves of their own (like Lithuania or Armenia);

- we can observe an obviously inverse correlation between the influence of financial potential and the degree of capital saturation in a country. In other words, countries in which capital saturation has already reached quite a satisfactory level do not require much extra financial resources to continue their economic development;

- generally speaking, the effect from capital and financial resources is nearly always declining over time. At the same time, different countries demonstrate very different levels of economic efficiency in their use of capital internally. This difference between the countries provokes cross-border flows of capital which is initiated - in the overwhelming majority of cases - by rich economies. Same conclusion has been previously achieved by [20] and also in [21];

Regardless the commonly known fact that all developing nations are always in need of additional financial resources, the stimulating impact of these resources is still much lower if compared with the impact of natural resource factor. This can be indirectly explained by the inevitable: capital has been always concentrated at stock exchanges located in the global centers of capitalism. Despite all the needs of developing nations and their promising potential, this capital does not want to move too far from the globally acknowledged stock markets [22].

Our last factor under consideration is the labour factor, see Table 7 for details.

Our calculations presented in Table 7 show that the influence of labour factor is especially meaningful for the most developed Western countries. Their economies are in constant need of higher productivity, efficiency and advanced innovations. The high-tech structure of their national economies requires human resources with sophisticated skills. In parallel to that, other, less developed countries, especially those located in Latin America and on the African continent, are developing primarily thanks to various other factors, not labour.

The correlation between the stimulating impact of the labour factor and the national human resource potential (measured as the number of currently employed people within the national economy) shows that the former (that is, the stimulating impact) does not really depend on the number of active labour force. In other words, economic efficiency of the labour resources' usage does not depend on how rich is a country in terms of labour potential and/or population number.

\section{Discussion and Conclusions}

In this study we have three factors of economic development which we consider to be of most vital importance for growth - natural resources, capital availability and labour/human resources. Concluding this research, we can state that contemporary economies differ between each other by the degree of influence imposed by each of these factors. In our opinion, the most interesting observation here is that the role of capital in an economy is gradually reducing in parallel to the growing rate of capital saturation [23]. At the same time, natural resources and labour/human resources remain to be roughly the same influential, even when their volumes in a country are already excessive.

Overall, our analysis of the selected macroeconomic indicators leads us to the following key conclusions:

The highest positive correlation (0.89) has been observed here between the labour resource factor and the GDP per capita indicator. At the same time, correlations between 
the impacts of natural and financial factors with GDP per capita is also strong but also negative ( -0.47 and -0.45 accordingly). This result can be interpreted as a statistical proof for the assumption that economic success of a nation depends, first and foremost, upon the quality (and productivity, and efficiency) of its human resources but not its location or the richness of its land.

This conclusion could and should be taken into consideration by the governments of those countries that are actively seeking cheap labour from abroad (Thailand, United Arab Emirates or Russia, for example). We are convinced that good-quality, stable economic development of a country can never be based on the labour of underqualified foreigners. Once the volume of unskilled immigration into a country achieves some critical level, the country would be forced to rely mostly on its financial resources and its mining sector. Here we need to keep in mind that the role of capital is never stable, and natural resources are never endless. In other words, the strategy based solely on the invited labour is a highly risky one. The source of key labour resources should always be internal and stable.

To some extent, the presence of a negative correlation between the labour factor and the macroeconomic growth for the most advanced economies seems to be even logical, as dependence on "borrowed labour" is a common specific features of many developed countries. At the same time, we should also note that the correlation between natural/financial resources on the one side and economic development rates on the other is positive for a long list of countries. This means that all these economies are growing extensively - actively using all "tangible" resources they are able to use. This is a peculiar feature of many developing nations, they are also "hungry for resources" of any possible type.

Additionally, we have also calculated the correlation between three indices of stimulating role (for three key factors as above) with the indices of international migration (in the same time period). Positive correlation (0.53) is observed between the labour factor impact and the rates of international migration. At the same time, correlations between the natural/financial resources and the rates of international migration are low and negative (0.22 and 0.2 accordingly).

Results on these groups of correlations indirectly prove, inter alia, that countries are capable to attract labour force from other countries not because they are rich in resources or because they are financially capable. Labour force is interested to enter those markets that demonstrate higher than average labour productivity and labour efficiency.

Today, many economies welcoming labour immigrants actually have rather limited potential for further growth (or stated differently, development of their economies is not faster than the inflow of extra workers into a country). Under such a scenario, the national economic system is always forced to raise internal labour productivity in order to survive. Survival and all further economic achievements of a country under this scenario will depend on the following two key preconditions:

Measures on the state level should be taken to guarantee that labour immigration into a country is of "good quality", that is, mostly skilled workers are coming to work in a country. Growing share of qualified labour resources would guarantee growing labour productivity in a long term.

State-level tools should be also implemented to make sure that domestic population is also well motivated to develop professionally, get better education (in the country, not abroad) and then apply the obtained skills on various local jobs.

Introducing these two directions into national migration and labour policies will make sure labour immigration into a country is oriented on the most skilled labour force. However, we also need to keep in mind that every nation must have its own, specific and well adjusted migration policy, oriented on the internal needs of a country and its population. 


\section{References}

1. O. Samosir, W. Rajagukguk, EUrASEANs 5(6), 27-39 (2017)

2. A. Curzio, M. Fortis, K. Zoboli, Innovation, Resources and Economic Growth. Economics of Growth and Technical Change (Cornwall, 1994)

3. R. Harrod, Economic Dynamics (Macmillan, London, 1973)

4. J. Hicks, The Mainspring of Economic Growth, Nobel Lectures, Economics 1969-1980 (World Scientific Publishing Co., Singapore, 1992)

5. J. Keynes, The General Theory of Employment, Interest and Money (1936)

6. I. Elokhova, E. Kozonogova, EUrASEANs 1(8), 7-19 (2018)

7. P. Aghion, P. Howitt, A model of growth through creative destruction (Massachusetts, 1990)

8. B. Amable, Endogenous Growth Theory, Convergence and Divergence. Economics of Growth and Technical Change (Cornwall, 1994)

9. E. Denison, The J. of Business 4, 61-63 (1962)

10. J. Clark, C. Freeman, L. Soete, Futures 13(4), $72-73$ (1981)

11. N. Kondratiev, The Major Cycles of the Conjuncture (1928)

12. S. Kuznets, Toward a Theory of Economic Growth, with Reflections on the Economic Growth of Modern Nations (1968)

13. W. Mitchell, J. Muysken, Full Employment Abandoned: Shifting Sands and Policy Failures (Edward Elgar Publishing, 2008)

14. J. Tinbergen, On the Theory of Economic Policy. Volume 1 of Contributions to Economic Analysis (North-Holland, Amsterdam, 1952)

15. D. Acemoglu, Quarterly Journal of Economics 113(4), 1055-1089 (1998)

16. H. Van, H. Mai, EUrASEANs 2(15), 50-59 (2019)

17. R. Day, Do Economies Diverge? Economics of Growth and Technical Change (Cornwall, 1994)

18. A. Př́vara, Transnational Marketing Journal 7(1), 59 - 72 (2019)

19. W. Mitchell, M. Joan, T. Van Veen, Growth and cohesion in the European Union: The Impact of Macroeconomic Policy (Edward Elgar Publishing, 2006)

20. P. Michaelides, J. Milios, A. Vouldis, Emil Lederer and the Schumpeter, Hilferding, Tugan-Baranowsky Nexus (University of London and University of Crete, Rethymnon, 2007)

21. R. Solow, The American Economic Review 64(2), 1-14 (1974)

22. J. Tobin, The New Palgrave Dictionary of Finance and Money (Palgrave, London, 1992)

23. A. Př́vara, Geographical Journal 71(2), 161-180 (2019) 